NBER WORKING PAPER SERIES

THE INELATIONARY PROCESS IN ISRAEL: SHOCKS AND ACCOMMODATION

\author{
Michael Bruno \\ Stanley Fischer
}

Working Paper No. 1483

\author{
NATIONAL BUREAU OF ECONOMTC RESEARCH \\ 1050 Massachusetts Avenue \\ Cambriage, MA 02138 \\ October 1984
}

The research reported here is part of the NBER's research program in Economic Fluctuations. Any opinions expressed are those of the authors and not those of the National Bureau of Economic Research. 
NBER Working Paper \#1483

october 1984

The Inflationary Process in Israe1:

Shocks and Accommodation

ABSTRACT

The rate of inflation in Israel increased from 8 percent in 1965 to $300-400$ percent in the first half of 1984. The inflationary process until 1977 was not qualitatively different from that in the OECD countries, but after the financial liberalization of 1977 the economy appeared to move into a new era in which the inflation rate seemed capable only of rising. Our explanation of the inflationary process is that because of institutional adaptations, and as a result of accommodating monetary and fiscel policies, the stabilizing forces in the economy are so weak that the inflation rate is in a neta-stable equilibrium. We ascribe the apparent asymmetry of the inflation to the expansionary underlying thrust of monetary and fiscal policy.

We develop an analytical framework that assigns roles to indexation, to the financial structure, and to the exchange rate system in determining the dynamics of the economy. We place very little blame for the inflation on wage indexation, which has been incomplete, but we regard the extensive indexation of the returns on financial assets, and the steady shift out of nominal assets, as major contributing factors, for the economy is now left with virtually no nominal anchor. The paper concludes with a brief discussion of alternative stabilization plans, arguing that a successful stabilization program will have to be comprehensive and rapid.

Stanley Fischer

Professor of Economics

Department of Economics

MIT E52-280A

Cambridge, MA 02139
Michael Bruno

Professor of Economics

Department of Economics

Hebrew University

Jerusalem, Israel

(617) $253-6666$ 
Michael Bruno and Stanley Fischer *

THE INFLATIONARY PROCESS IN ISRAEL: SHOCKS AND ACCOMODATION

Israel's annual inflation rate increased from 8 percent in 1965 to $300-400$ percent in the first half of 1984. Up to 1977, the process of inflation in Israel does not appear qualitatively different from that in the OECD countries (see Bruno in this volume). Indeed, even after it jumped to $40-$ 50 percent after the Yom Kippur War, the inflation rate declined slowly until, by the first half of 1977 , prices were rising at an annual rate of 25 percent. After the financial liberalization of late 1977, the economy appeared to move into a new era, with inflation firmly entrenched, and seemingly capable only of rising.

In this paper we provide an overview and analysis of the inflationary process, seeking to explain the increases in the inflation rate and the forces that keep it high and, on occasion, rising. There has been no shortage of explanations of inflation: it has been ascribed to indexation, to monetary policy, to the budget deficit, to the introduction of floating exchange rates, to "bubbles" - self-justifying expectations of inflation to name only some of the most prominent. Several of these explanations provide necessary conditions for the continuation of the process, as we shall show below.

\footnotetext{
*Department of Economics, Hebrew University and M.I.T. respectively, and Research Associates, N.B.E.R. This paper was prepared for the volume, The Economy of Israel: Maturing Through Crisis, edited by Yoram Ben-Porath, Falk Institution, Jerusalem, 1984. It was written while Fischer was Max Bogen Visiting Professor of Economics at the Hebrew University in the Spring of 1984. We are grateful to Carlos Bachrach for research assistance and the National Science Foundation for financial support. We are indebted to Yoram Ben-Porath and Rafi Melnick for helpful comments on an earlier draft. While we write of inflation in the presert tense in the paper, we of course hope that the past tense will be more appropriate by the time
c. printing.
} 
Taking as given successive governments' reluctance to force the inflation rate down through restrictive policy that might produce a major recession, there remain serious economic questions about the forces driving the inflationary process and the institutional adaptations that permit the economy to operate at a reasonable level of efficiency despite inflation. In a nutshell, our explanation of the inflation will be that because of institutional adaptations, and as a result of accommodating monetary and fiscal policies, the stabilizing forces in the economy are very weak, leaving the inflation rate in a meta-stable equilibrium. This means that the inflation rate could come down as well as rise, but the underlying thrust of fiscal and monetary policies during the period has been expansionary, with the result that the adaptation of the inflationary process, including expectations formation, has been smoother upwards and more rigid downwards, even when cost-reducing factors were occasionally operative.

In developing our analytical framework below we assign roles to indexation, to financial structure, and to the exchange rate system in determining the dynamics of the economy. We also place emphasis on fiscal and monetary policies that have permitted the inflation to continue. Before developing the analytical framework, we provide a brief overview of phases in the inflationary process since 1960.

\section{THE PHASES OF INFLATION}

Figure 1 and Table 1 provide an overview of the inflationary history of the economy in the period since 1960 together with the growth rate of real output; Table 2 provides summary data on policy and other macroeconomic 
variables over the period. The increase in the inflation rate from the 510 percent range of the early 1960 s to the $300-400$ percent range of the first half of 1984 can be broken down into eight phases (see Table 1).

PHASE 1: Normal Growth, 1960 to $1965: 1$

The inflation rate in the first half of the 1960 s averaged 7 percent, while GNP was growing at an annual average rate of 10 percent. The inflation rate was high by international standards, the growth rate of output by the same standards even higher. The government budget over the period was balanced. The major problem facing the economy at this time was the current account deficit. An overheated economy (inflation reached 8 percent in 1965-66) led to the adoption of sharply restrictive domestic policies which, together with an exogenous decline in the rate of immigration and a consequent decline in aggregate demand, produced the 1966-67 recession.

PHASE 2: Recession, 1965:1 to $1967: 2$

The unemployment rate rose to 12 percent (see Figure 3) while the inflation rate dropped to less than 2 percent. As is usual in recessions, the rate of unemployment started rising before there was any pronounced fall in inflation. Nonetheless, within two years there had been a decisive, and subsequently long-lived, reduction in the inflation rate.

PHASE 3: Recovery, 1967:2 to 1970:1

The recession was drawing to an end before the Six Day War broke out in June 1967 (the growth rate for 1966 was 0.9 percent and for 1967 it was 2.3 percent). The war was followed by a period of extremely rapid growth, 
with low inflation, based in part on the absorption of those still unemployed at the end of the recession and in part on inflows of labor from abroad and the administered territories.

PHASE 4: Boom, 1970:1 to 1973:3

Growth continued at a rapid pace in the first two years of the 1970 s, but with the economy reaching the full employment zone, inflation accelerated to an annual rate of 22 percent. The variability of the inflation rate also increased, as a result of fluctuations in the exchange rate and of the occasional adoption of incomes policies.

PHASE 5: War and Oil Shock, 1973:4 to 1977:2

The growth rates of both output and productivity dropped sharply; inflation accelerated to an annual average rate of 37 percent, with accompanying high variability, due to the rise in import prices and to a series of sharp devaluations up to June 1975, when a crawling peg was instituted and maintained until 1977, aided by a one-time 10 percent devaluatión iñ September 1975.

PHASE 6: Traverse, 1977:3 to 1979:3

The period started with the liberalization of foreign exchange transactions in October 1977. The liberalization allowed Israelis to hold foreign currency accounts at home and abroad, as well as to hold limited amounts of foreign currency in cash. Virtually all foreign exchange controls were lifted; export subsidies and import tariffs were also reduced. This was accompanied by a sharp 50 percent devaluation of the currency, without other restrictive measures being taken. The major jump in the inflation 
rate nonetheless came some time after the foreign exchange liberalization.

This period of transition to three digit inflation rates will receive particular attention in our subsequent analysis.

\section{PHASE 7: Inflation P1ateau, 1979:4 to $1983: 3$}

This four-year period of high inflation (at annual average rates between 100 and 130 percent) is quite remarkable. In spite of the higher average inflation rate, the variability of quarterly inflation as measured by its standard deviation was actually lower in absolute terms than in the two previous phases. A failed attempt at stabilization by a sustained slowdown in the rate of devaluation ended in a major devaluation in October 1983, accompanied by a collapse of the value of bank shares, hitherto a major financial asset.

\section{PHASE 8: Runaway Inflation?}

The October 1983 devaluation and subsidy cuts resulted in a rapid rise in the price level; in October the rate of inflation was 21 percent. The new

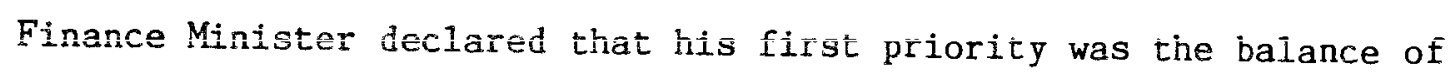
payments; the implication was that the inflation rate would be allowed to increase if that was necessary to improve the current account deficit, which in the third quarter of 1983 had reached an annual rate of six billion dollars or 25 percent of GDP.

In the event inflation did rise rapidly, to an annual rate of 400 percent (compounded monthly) for the first five months of 1984. With elections approaching in JuIy 1984, the economic situation at the time of writing was both unclear and volatile. 
II. ANALYTICAL FRAMEWORK

We use a standard aggregate supply-demand framework to analyze inflation. The particular Israeli emphasis comes in the description of the properties of assets and of wage indexation, in the policy choices that make the growth rate of money and the composition of the outstanding stock of government debt endogenous, and in the magnitudes of the government and current account deficits that drive the processes of accumulation of domestic government and foreign debts.

The position of the aggregate supply (AS) schedule depends on wages and associated payroll taxes, raw material prices, the cost of capital, and technology; the position of the aggregate demand (AD) curve is determined by the value, 1iquidity, and composition of wealth, by the exchange rate and foreign variables - demand, prices, and interest rates - by fiscal policy variables, and by expectations of inflation and exchange rate changes. Continuous shifts in the aggregate supply and demand curves trace out the changing price level and output.

To analyze the dynamics of inflation, we write the aggregate supply and demand curves (which relate output to the nominal price level) as functions of their major driving variables. Thus,

$$
Y_{S}=g(W / P, E / P, t, a)
$$

Here $Y_{S}$ is the supply of output, $W$ is the nominal wage (as a cost to the employer, and thus including payroll taxes), $\mathrm{P}$ is the price level, $E$ is the nominal exchange rate that determines the domestic cost of imported raw materials, $t$ is a variable representing the state of technology, and a represents missing supply variables, movements in which 
can be thought of as supply shocks (e.g., the world price of raw materials).

On the aggregate demand side we have

$$
Y_{d}=f\left(H / P, V, G-T, E / P, Y^{*}, \pi^{e}, z\right)
$$

We represent aggregate demand $\left(Y_{d}\right)$ as a function of the real stock of high-powered money $(H / P)$, real wealth $(V)$, the government domestic demand surplus $(G-T)$, the real exchange rate $(E / P)$, foreign income $\left(Y^{*}\right)$, the expected rate of inflation $\left(\pi^{e}\right)$, and $z$, a demand shock variable representing also omitted demand factors. We shall subsequent1y consider the domestic budget deficit as a fraction $(\delta)$ of GNP. Because there is no agreed-upon measure of the liquidity of the stock of assets, we omit that determinant of aggregate demand from (2).

To understand the dynamics of the inflationary process, we need to analyze the determinants and dynamics of the variables specified in the aggregate supp1y and demand curves (1) and (2). Starting on the aggregate supply side, wages are determined in bi-annual wage negotiations that fix a base wage level and indexation formulae for the adjustment of the wage to changes in the price level. Typically the indexation clauses have provided for partial (70-80 percent), semi-annual and subsequent1y quarterly, compensation for price changes. The non-adjustment of wages for a period of three months at high rates of inflation makes for a marked withinquarter variation of wages; the less-than-complete compensation for inflation means that real wages at very high rates of inflation would fall rapidly over the life of a contract. ${ }^{1}$ This account of the wage adjustment process makes it difficult to blame indexation as the main factor determining the behavior of wages, since even in the short run there are 
always discretionary elements in the wage-setting process.

The second argument in the supply function is the real exchange rate, representing the prices of imported raw materials. ${ }^{2}$ A depreciation or devaluation (increase in E) will shift the AS schedule up, tending to increase prices and reduce output. If the Bank of Israel follows a purchasing power parity (PPP) rule, then domestic price level shocks are automatically transformed into inflationary exchange rate changes. We sha11 later discuss the behavior of the economy when the government was following a set of operating rules that include PPP for control of the exchange rate (from around 1975 onwards).

Many of the most significant factors in the Israeli inflation enter in the first three arguments of the aggregate demand function (2), in the interaction of monetary and fiscal policies and in the dynamics of asset supplies. Private sector wealth consists of some nominal assets, largely currency and demand deposits, of various government liabilities indexed to either the price level or the foreign exchange rate, of some foreign assets, and consumer durables, housing, and private ownership of corporations. We simplify by concentrating on the stock of high-powered money, $\mathrm{H}$, government bonds indexed to the price level $\left(B_{p}\right)$, government bonds indexed to the exchange rate $\left(B_{f}\right)$, and direct ownership of foreign exchange $(F)$. Thus, wealth is given by:

1 Special indexation adjustments to wages are paid more frequently than quarterly if the inflation rate exceeds a specified level. For more details on wage indexation see Kleiman's chapter in this volume.

2 We do not explicitly discuss other factors affecting the rate of shift of the aggregate supply curve beyond noting that supply factors played a significant role in the slowdown of growth in Israel since the early $1970^{\prime}$ 's (see Bruno in this volume). The growth slowdown in turn affected the inflation rate, as we discuss below. 


$$
V=H / P+B_{p}+E \cdot B_{f} / P+E \cdot F / P
$$

In (3) $B_{f}$ and $F$ are the foreign-currency denominated values of holdings of foreign-currency linked bonds and foreign currency respectively. The dynamics of inflation in Israel is significantly affected by the fact that domestic bonds $\left(B_{p}\right)$ are fixed in real value, and that the nominal value of much of the remainder of the government debt $\left(E \cdot B_{f}\right)$ automatically increases when there is a devaluation. Thus the Israeli economy does not have the automatic inflation stabilizer that an increase in the price level and/or the exchange rate reduces real private sector wealth by reducing the real value of the outstanding stock of government debt, except for the possibility that the real value of the monetary base would fall. Indeed, if the government is pursuing a PPP exchange rate policy, then any domestic inflationary shock automatically increases the nominal value of wealth virtually pari passu.

Examining the aggregate demand function (2), and assuming both that the government budget deficit is fixed in real terms ${ }^{3}$ and that the exchange rate is determined by PPP, we see that the only potential element of non-homogeneity or non-accommodation to price rises on the demand side is $H$, the nominal stock of high powered money. The monetary base, $H$, is a small nominal magnitude with which to control the price level (assuming a given real exchange rate and real wage) so that even if $H$ were held strictly constant when the price level rose, it might be ex-

3 In fact, there have been two elements making for an increase in the real deficit with a rise in the price level - one was the un-indexed debt of the private sector (which by 1984 has virtually been eroded by inflation) and the other was the lag in the collection of taxes. 
pected to exert at best a small and slow stabilizing influence.

Such stabilization would arise from the rise in the rate of interest caused by the reduction in the real money base. But suppose the monetary authority is attempting to control the real rate of interest, as it has in Israel. Then the quantity of high-powered money becomes endogenous, and in response to an increase in the price level and consequent upward pres-sure on the interest rate, the stock of high-powered money is increased. Thus the stabilizing element that could have been provided by keeping $\mathrm{H}$ to a prescribed path is lost. There would accordingly be no forces on the demand side of the economy tending to resist rising prices. ${ }^{4}$ The price level then does not tend to return to its original level, or to any equilibrium level, unless some element of policy - be it monetary or fiscal is directed to that end.

The above discussion implies that we could expect the aggregate demand $(A D)$ schedule to be quite steep or virtually vertical. The very short-run AS curve, on the other hand, will be considerably flatter, because of imperfect wage indexation (see previous discussion) and as long as the economy is operating below capacity (which it did in the mid1970s); the short run is defined here as the indexation period for wages.

4 A further difficulty has been pointed out to us by Rafi Melnick. In the semi-conventional ful1-employment IS-LM model with nominal bonds, and with policy that fixes the real interest rate (assume adaptative expectations to avoid well-known problems of indeterminacy when expectations are rationa1), goods market equilibrium determines the real value of wealth. The appropriate interest rate is then enforced through open market operations in which bonds and money are exchanged. However, if money is the only nominal asset, and the real value of wealth is determined in the goods market, the real value of money balances are also determined. Then, given the conventional demand for money function, there may be an inconsistency between the specified interest rate that clears the goods market and the rate that clears the money market. The inconsistency is removed if output becomes endogenous. 
However, since wages have also been effectively indexed, though at a time lag (which has become shorter over time), one could expect greater steepness of the AS curve as one moves from the very short run (say, a quarter or less) to somewhat longer time spans (say, six months or more). The price level may thus become very sensitive to shocks. As we shall see, this problem has worsened as the inflationary process accelerated towards the end of the 1970s.

The steepness of the $A D$ curve and relative flatness of the short run AS curve would imply that in the short run price level changes would mainly be affected by cost factors (wages and input prices) and less by demand shifts, while demand shifts would feature large in short-run output changes (see Bruno in this volume).

Equating the supply (1) and the demand (2) relationships and looking at the implied equilibrium in rate-of-change form we rnay write down the rate of change of the price level $(\dot{P} / \mathrm{P}=\pi)$ as a linear function of the rates of change of the three key nominal magnitudes: the nominal wage $(\dot{w}=\dot{W} / W)$, the exchange rate $(\dot{e}=\dot{E} / E)$, and the money base $(\dot{\mathrm{m}}=\dot{H} / H)$, plus supply shift $\left(\mu_{s}\right)$ and demand shift $\left(\mu_{d}\right)$ factors. These are combined into one factor ( $\mu$ ) which can be expected to be dominated by the supply side.

$$
\pi=\dot{p}=a_{1} \dot{w}+a_{2} \dot{e}+a_{3} \dot{m}+\mu
$$

where $p=\log \mathrm{P}, \mathrm{m}=\log \mathrm{H}, \mathrm{w}=\log \mathrm{W}, \mathrm{e}=\log \mathrm{E}$.

The description of the price dynamics can be completed by writing down a Philips-type equation for wages as a function of prices and labormarket slack, and adjustment rules for the exchange rate and the money 
base during periods for which these could not be considered exogenously determined.

Consider now the longer-run implications of such price dynamics when the above nominal magnitudes are themselves each indexed to past inflation $\left(\pi_{-1}\right)$ and/or to inflationary expectations $\left(\pi^{e}\right)$. If the system is homogeneous we could summarize the inflationary process in the form

$$
\pi_{t}=\alpha \pi_{t-1}+(1-\alpha) \pi_{t}^{e}+\varepsilon_{t}
$$

where $\varepsilon_{t}$ is a summary statistic involving supply and demand shocks, $\mu$, as well as shocks to $w, e$, and $m$.

Suppose that expectations are adaptive, with coefficient of adaptation $\beta$, so that

$$
\pi_{t}^{e}=\beta \pi_{t-1}+(1-\beta) \pi_{t-1}^{e}
$$

Solving (5) and (6) we obtain:

$$
\pi_{t}-\pi_{t-1}=\varepsilon_{t}-(1-a)(1-\beta) \sum_{i=1}^{\infty}[\alpha(1-\beta)]^{i-1} \varepsilon_{t-i} .
$$

Equation (7) shows that when $(1-\alpha)(1-\beta)$ becomes very sma11, 5 a positive shock $\varepsilon_{t}>0$ will be transmitted into an immediate jump in the inflation rate $\left(\Delta \pi_{t}=\pi_{t}-\pi_{t-1}>0\right)$ rather than just a jump in the

5 As the degree of inflation itself accelerates the degree of persistence $\alpha$ (i.e., direct indexation of the nominal magnitudes) will tend to increase towards unity. Likewise, the coefficient of adaptation of expectations ( $B$ ) rises towards unity. 
price 1evel. ${ }^{6}$ Thus, one puzzling feature of the Israeli inflation the apparent tendency for a shock to the price level (such as a devaluation) to result in a permanent change in the inflation rate - can be explained as a result of accommodating macro policies.

But there is a second feature of the inflation that needs explanation: the inflation rate jumps up quite readily but does not fall in the same way. Suppose the indexation or the expectation-formation mechanisms are not symmetric upwards and downwards. The coefficient of adaptation ( $\beta$ ) is likely to depend on the state of the economy as perceived by individuals and firms. For example, when the general thrust of fiscal and monetary policy is highly expansionary and there is a temporary unexpected downward shift in inflation in period $t-1\left(\pi_{t-1}-\pi_{t-1}^{e}<0\right), \beta$ may be very small (or zero) so that expectations are not revised downward [i.e., in equation (6) we get $\pi_{t}^{e} \sim \pi_{t-1}^{e}$ even though $\pi_{t-1}<\pi_{t-1}^{e}$ ], while $\beta$ would be large (or close to 1 ) when the unexpected shock is positive $\left(\pi_{t-1}>\pi_{t-1}^{e}\right)$. The effect of such asymmetries is to make a sequence of positive and negative shocks of zero mean impart an upward thrust to the inflation rate.

If the inflation rate follows the random walk implied by (7) when $\alpha=1$ or $\beta=1$, then the inflation rate could, in the long $r u n$, be at any level. But if $\alpha$ is slightly less than one, that is, if there is any element of non-homogeneity in the equation for the inflation rate, the

6

If expectations are rational, we obtain

(7') $\pi_{t}=\pi_{t-1}+\varepsilon_{t}+[(1-\alpha) / \alpha]_{t-1} \varepsilon_{t}$, where ${ }_{t-1} \varepsilon_{t}$ is the expectation, formed at $(t-1)$, of $\varepsilon_{t}$. In this case the key determinant of the behavior of the inflation rate is $\alpha$. 
system will tend - perhaps very slowly - to return to an equilibrium longrun inflation rate. 7

In particular, fiscal policy considerations may determine the average growth rate of money, through the government budget constraint, even if monetary policy does not pursue explicit monetary growth targets. We can write the government budget constraint as

$$
G-T=\delta Y=\dot{H} / P+\dot{B},
$$

where the dot indicates the change in a variable. We here suppress the difference between bonds indexed to the domestic price level and to the exchange rate, and omit direct government sales of foreign exchange, which will be added subsequently .

In steady state, the ratios $H /(P \cdot Y)$ and $B / Y$, where $Y$ is real $G N P$, are constant. Accordingly in steady state, the growth rate of high-powered money $\dot{H} / H(\dot{m})$ is equal to the inflation rate $(\pi)$ plus the growth rate of output $\left(g_{y}\right)$ :

$$
\dot{\mathrm{m}}=\pi+g_{\mathrm{y}} \text {. }
$$

Similarly, the growth rate of bonds $\left(g_{b}\right)$ is equal to the growth rate of output $\left(g_{y}\right)$ :

$$
g_{b}=g_{y}
$$

7

Note the distinction between the questions of whether the price level or the inflation rate returns to a steady state level. Suppose the inflation rate is described by $\pi_{t}=\alpha+0.95 \pi_{t-1}+\varepsilon_{t}$ where $\varepsilon_{t}$ is white noise. Then the expected long-run rate of inflation is determinate and equal to $[\alpha /(1-0.95)=20 \alpha]$. But shocks to the price leve1 are permanent. If the price level jumps by 10 percent today there is no expectation that subsequently the price level will tend to return to its original level or expected path. 
Accordingly, in steady state the government budget constraint becomes

$$
\delta=\left(\pi+g_{y}\right)(H / P Y)+g_{y}(B / Y)
$$

Now let $h$ denote the ratio of the stock of real high-powered money to nominal GNP (H/PY), and $b$ the ratio of bonds to GNP (B/Y). Then,

$$
\pi=\left[\delta-g_{y} \cdot(h+b)\right] / h \text {. }
$$

Equation (12) gives one approach to analyzing the determinants of the growth rate of the monetary base and thus, in steady state, of the inflation rate. The term following $g_{y}$ in the denominator in (12) is the amount of the deficit that can be financed by the government through the sale of bonds and printing of money without increasing their respective ratios to GNP. The more rapid the growth rate of output, the greater the share of the deficit that can be financed in a non-inflationary way. The larger the government deficit, $\delta$, the higher the inflation rate in the steady state. And the larger the monetary base, the lower the inflation rate need be. 8

The government budget deficit obviously plays a major role in this stea úy-state analȳisis. There is no reason, though, to expect a close short-run connection between the inflation rate and the size of the government budget deficit. For it has to be remembered, when using the

8

A more complete analysis takes into account the dependence of $h$ in the denominator of (12) on the expected inflation rate, and raises the possibility that there are two equilibria for the economy at which a given amount of revenue from the printing of money can be obtained one at a relatively low inflation rate, and one at a higher rate. We regard this possibility as more than a theoretical curiosity as we shall note when discussing the Israeli experience below. The analysis can also be extended to study the non-steady state dynamics of inflation, and to recognize that $b$ depends on the real interest rate. 
approach implied by (12), that we used the quantity theory in equation (9) to link the inflation rate to the growth rate of money in the steady state. But in the short run there is at best a very loose connection between the growth rate of the stock of high-powered money and inflation. We can now extend the government budget constraint ( 8 ) to include the government's foreign account and changes in the government's foreign debt (ंF). We get:

$$
\left(\delta+\delta_{f}\right) \cdot Y=\dot{H} / P+\dot{B}+E \cdot \dot{F} G / P
$$

Here $\delta_{f}$ is the government's external deficit as a percentage of GNP. The external deficit (sometimes a surplus) is equal to the deficit on goods and services minus unilateral transfers. 9

Equation $\left(8^{\circ}\right)$, the overall government budget constraint, shows that the government finances its total deficit in three ways: through the printing of high-powered money, through sales of bonds (indexed either to the price level or to the exchange rate) and through borrowing abroad. Sales of foreign exchange to domestic residents, one way of financing a domestic deficit, do not necessarily imply increases in foreign indebtedness of the government: if the government has an overall foreign surplus, then the sale of foreign exchange is merely the means through which the foreign surplus finances part of the domestic deficit. It should be noted that FG is the government's net foriegn debt. Thus if the government runs down foreign exchange reserves to sell foreign currency to domestic residents it is, in terms of $\left(8^{\prime}\right)$, engaging in foreign borrowing.

9

Capital gains or losses on the oustanding debt have to be treated consistently in defining the service account and the external deficit. 
The use of the government budget constraint ( 8$)$ or $\left(8^{\prime}\right)$ does not necessarily imply that the government consciously decides on a particular growth rate of high-powered money as a means of financing its budget deficit. Rather, in the Israeli context, it is much more likely that the government turns to printing money as its last resort in budget financing. First it decides what it needs to spend and how much it can raise through taxes (and foreign borrowing), then it sells as many bonds as it can at the existing interest rate, and the rest is financed by printing money. 10 Relatively sma11 changes in the deficit would be consistent in the long run with major changes in the growth rate of $\mathrm{H}$, and thus of inflation, according to this approach. But the transitional costs of moving from a high-inflation to a low-inflation equilibrium could be sufficient to inhibit such a change. We believe this to be particularly important in the Israeli context.

The current stock of government debt is the result of past deficits, and the prospective size of the debt is a function of expected deficits. A large current debt may inhibit monetary policy by preventing aggressive use of interest rate variations for current stabilization purposes, for fear that increasing interest rates would significant1y increase the budget deficit or thwart the finance of future deficits because of fluctuations in bond prices. Prospective deficits influence aggregate demand and the terms at which the government can obtain both current and future financing.

The analytical framework presented in this section is reasonably conventional. The major departure from standard macroeconomic models 1ies

10 See also Fischer (1984). 
in the structure of assets, for wage indexation is found in many countries. As we sha11 argue below, abnormal macroeconomic behavior in Israel has to be attributed at least as much to specific policy choices that, for instance, produce large budget deficits, and/or endogenize the rate of growth of money, as to peculiar structural characteristics of the economy.

III. ANALYSIS OF THE INFLATIONARY ECONOMY

Policy since 1965 has been significantly affected by the experience of the 1965-67 recession, when restrictive policies were implemented primarily to bring the current account deficit closer to balance, but also to counteract the then high ( 8 percent) rate of inflation. The resultant unemployment of more than 10 percent brought both social demoralization and emigration, with the result that maintenance of low rates of unemployment was considered a major policy goal during the crises of the 1970s. Despite the rising rate of inflation since 1970 , there has been no strong political support for policies that would attempt to control inflation at the expense of temporary unemployment. Widespread indexation, particularly of asset returns, reduced the perceived and actual costs of any given rate of inflation and helped keep inflation from becoming the dominant economic policy issue.

The major features of the inflation process that were seen in Figure 1 are the generally rising trend of the inflation rate since 1965, and the apparent step nature of the changes. To understand the inflation process we have to understand both why the inflation rate has been on a rising trend, and the reasons for the jumps. 


\section{Inflation Dynamics}

On the demand side, we shall argue, expansive fiscal policy and accommodative monetary and exchange-rate policy have generally combined to maintain upward pressure on the price level and the rate of inflation and as a result of the structure of the financial system and the policy choices, the automatic forces that could stabilize inflation in response to supply shocks are very weak. Favorable shocks were usually exploited to help expand demand (in the last few years, consumption) and output while unfavorable ones were not counteracted for any length of time by restrictive discretionary policy. Temporary contractionary policies were undertaken (as in 1975-77 and in 1980); they were usually accompanied by costincreasing measures (devaluation, indirect taxes, and a cut in subsidies) which pushed up the AS curve, while the flatness of the AS curve implied that contraction showed up in output rather than in prices. A short run account of inflationary dynamics will then be dominated by supply-side factors to which we turn first. The important underlying role of the budget deficit and of the monetary system in accounting for shifts in long-run steady state inflation will be taken up subsequently.

The cost-side dynamics of inflation has featured in several accounts of the inflationary process in the 1960 s and early 1970s, the best known being a pair of annual wage and consumer-price equations for the period 1958-1975 by Artstein and Sussman (1977). ${ }^{11}$ Prices are a function of wages and import prices plus a small, hardly significant, role for money, while

11 This is discussed briefly in another chapter in this volume and will not be repeated here. For a quarterly regression of the same kind see Bruno and Sussman (1979). After 1977 regressions based on annual data would miss a considerable part of the dynamics. See also Zilberman (1984). 
wages are a function of prices, unemployment, and the increased labor supply from the territories (a very important wage-moderating factor in the years 1968-1972).

It can be argued ${ }^{12}$ that with a high degree of correlation between the nominal magnitudes (prices, wages, exchange rates, and money) price equations of the typical kind are difficult to interpret, especially after 1975. However, this problem can be partly side-stepped by running such an equation in real terms, namely, in the form of first differences with respect to past inflation. The following equation is obtained, in terms of wholesale prices (to neutralize, to the extent possible, subsidies and demand elements) for the 66 quarters $1966: 3$ to $1982: 4^{13}$ -

$$
\begin{aligned}
\dot{p}-\dot{p}_{-1}=\frac{-0.26+0.35\left(\dot{w}-\dot{p}_{-1}\right)+\underset{(0.05)}{(0.36)(0.09)}}{0.28\left(\dot{p}_{n}-\dot{p}_{-1}\right)} & \\
& \text { D.W. }=2.01 \\
\bar{R}^{2}= & 0.46
\end{aligned}
$$

where $\mathrm{P}_{\mathrm{n}}$ is import prices.

An attempt to add monetary variabies to this equation on the whole fails, with the exception of an apparent five-quarter-lagged effect of

12 As recently shown by Melnick (unpublished study).

13 The correlation coefficient $(\rho)$ between $\dot{w}-\dot{p}_{-1}$ and $\dot{p}_{n}-\dot{p}_{-1}$ for the whole period $66: 3-82: 4$ is 0.24 , but this turns out to be dominated by high collinearity during the first oil crisis 73:4-77:1 $(\rho=0.571)$ while the correlation is virtually nil in all other periods: $66: 3-77: 3$ $(\rho=-0.025), 77: 2-82: 4(\rho=0.066)$. The equation was also tested for the implied homogeneity assumption by adding $\dot{\mathrm{p}}_{-1}$ to the right-hand side. This gives a zero coefficient $(-0.005$ with standard error 0.037$)$. It is also remarkably stable with respect to length of period or breakup into sub-periods. 
real credit expansion on inflation during 79:4-82:4. We sha11 come back to the important role of real import prices and real credit expansion in the traverse to the higher inflation plateau.

Continuing in the line of cost-side adjustments in the inflationary process we recall the argument that wages (w) can in turn be related to lagged inflation. Likewise, the exchange rate followed an approximate PPP rule (plus occasional jumps) since the introduction of the crawling peg in 1975:3.

Instead of fitting an equation like (13) we could therefore run a regression of inflation acceleration $\left(\dot{\mathrm{p}}-\dot{\mathrm{p}}_{-1}\right)$ on its own past lags plus the acceleration in exchange rate adjustment $\left(\dot{\mathrm{e}}-\dot{\mathrm{e}}_{-1}\right)$. Using four-quarter lags and running the regression over sub-periods during 1965:1 to $1982: 4$ we find coefficients of $0.20-0.29$ for $\left(\dot{e}-\dot{e}_{-1}\right)$, similar to the ones found in the previous regression and also in Artstein and Sussman (1977); we also test and find that the inflation rate is homogeneous in terms of its own past lags. ${ }^{14}$ What is more interesting is the finding, already recorded by Gottlieb and Piterman (1982), that the share of quarterly inflation 'explained' by the inflation of the previous two quarters continuously rises over time. The implied coefficients are, respectively,

14 This is done by adding $\dot{\mathrm{p}}_{-4}$ in the regression of $\left(\dot{\mathrm{p}}-\dot{\mathrm{p}}_{-1}\right)$ on its own three lags [down to $\left(\dot{\mathrm{p}}_{-3}-\dot{\mathrm{p}}_{-4}\right)$ ] and testing for a zero coefficient on $\dot{p}_{-4}$. The implied coefficients for the lagged inflation rates are then worked out. Here the CPI index was used for p. 


\begin{tabular}{ccccc} 
& $\begin{array}{c}\text { Number of } \\
\text { observations }\end{array}$ & $\dot{p}_{-1}$ & $\dot{\mathrm{p}}_{-2}$ & $\begin{array}{c}\text { Sum of } \dot{\mathrm{p}}_{-1} \\
\text { and } \dot{\mathrm{p}}_{-2}\end{array}$ \\
\hline $1965: 1-71: 1$ & 25 & 0.37 & 0.19 & 0.56 \\
$1971: 2-75: 2$ & 17 & 0.32 & -0.24 & 0.08 \\
$1975: 3-78: 4$ & 14 & 0.51 & 0.36 & 0.87 \\
$1979: 1-82: 4$ & 16 & 0.62 & 0.42 & 1.04
\end{tabular}

$1975: 3-82: 4$

30

0.59

0.37

0.96

This is evidence of the considerable inertia (autoregressive nature) of the inflationary process as well as of the shortening of the $\mathrm{lag}$ in the implicit indexation of all nominal magnitudes (including faster monetary accomodation).

At this point we may also mention the asymmetric response to upward and downward inflationary shocks. When we add the acceleration in prices of controlled (subsidized) products $\left(\Delta \dot{p}_{k}\right)$ to the same regression together with the acceleration in exchange rates $(\Delta \dot{e})$, this time allowing for a different response to positive and negative shocks, we find the following coefficients (for the period 1975:3-1983:1) -

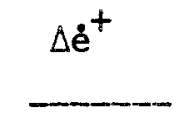

0.284

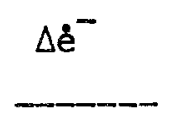

0.002

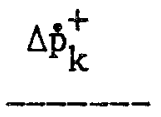

0.320

$(0.143)$

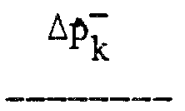

$-0.003$

$(0.121)$

As already noted in Section II, expectations and price linkages are asymetric when the general economic climate is an expansionary one. When the government is running a large and persistent deficit which 
shows no evidence of declining, cost reduction will be perceived as only temporary. We shall later mention an application of this feature to the recent dis-inflation experience of 1981-82. At this point it is appropriate to turn to the role of fiscal and monetary variables.

\section{The Policy Variables}

Table 2 shows the government budget deficit over successive periods since 1960. It gives both the domestic budget deficit (column 4) as a measure of the contribution of the government to domestic demand, and the overall budget deficit (column 5) including the government's current account (of the balance of payments) deficit; the overall deficit is an indication of the rate of change of government debt - internal and external - plus money printing. The domestic deficit climbed sharply as a percentage of GDP over successive periods from the start of the 1960 s till shortly after the Yom Kippur War. It then remained more-or-less constant, before falling somewhat in 1982 and 1983. It is not only the trend in the domestic deficit that is noteworthy, but also its absolute size; the deficit is extremely large by international standards. With the growth rate of GNP very high until 1973, large deficits could be sustained without much growth in the debt/GDP ratio. But with the average deficit in excess of 15 percent of GDP since 1974, with money financing covering less than one fifth of the deficit, and with GDP growing at only 3 percent, the debt/GDP ratio has risen sharply.

Table 3 presents indicators of monetary policy actions over the same period. The increase in the growth rate of high-powered money from period to period stands out clearly, as does the increase in the growth rate of other nominal magnitudes. However, much of this latter growth is 
automatic, as a result of the indexation of asset returns to either the price level or the exchange rate. The table also includes measures of the real interest rate on government bonds over the period since 1975 . These have been impressively stable, a result both of the institutional detail that the Knesset fixes the real interest rate on new issues, and of the reluctance of the Bank of Israel to allow prices of bonds to fluctuate in the secondary market. 15

The policy picture, then, is one of generally expansive fiscal and monetary policy, of stabilization of the real interest rate, and of following a PPP rule for the exchange rate during much of the period.

\section{The Transition to Three-Digit Inflation}

The major movement in the inflation rate after 1977 is associated with the massive devaluation that accompanied the foreign exchange liberalization at the end of 1977. Over the two quarters from $1977: 3$ to $1978: 1$, the real dollar exchange rate rose by 30 percent. (It was less when measured against a basket of currencies, due to the dollar appreciation.) Because the depreciation was accompanied by reduced tariffs and subsidies, the effective exchange rate feli by less, thus mitigating the cost-push effects, but still leaving a large (20 percent) increase in the real cost of imported inputs. In addition, the value of dollar-linked assets rose considerably, creating demand-side inflationary pressures. By the middle of 1978 the one-time shock of the devaluation appeared to be over, with the inflation rate back to the level of the plateau from which it had started in 1977.

15 There have, however, been periods during which the Bank of Israel has allowed the interest rate on bank loans (as opposed to government bonds) to change. 
But then, in the second half of 1978 , the inflation rate began its climb to the three-digit range, which was reached at the end of 1979. What was the source of this rapid jump? There was some cost pressure from wages, which rose 6 percent in real terms in 1978, partly through delayed indexation and partly as a result of wage negotiations, but no other major cost-push factor operated at the time: the second oil shock came only in 1979; the real exchange rate did not depreciate much further after the first quarter of 1978 and, indeed, appreciated in the fourth quarter of 1978 .

On the demand side, fiscal policy during 1978 was more expansionary than in 1977, with the domestic and total deficits well above the 1976-77 levels. Here was one expansionary factor. The monetary base grew by only 28 percent while prices rose by 48 percent over the year. However, the money stock $\left(M_{1}\right)$ increased at 45 percent annually while bank credit rose 80 percent. Studies of the demand for money typically find a significant shift in demand, during 1978, away from assets denominated in local currency. ${ }^{16}$ Consistent with the econometric result is the fact that there was a major shift into PATAM (dollar-linked) accounts during 1978, during which year ways were discovereu of using PATAMí in current transactions. 17

For example, Melnick (1983); Leiderman and Marom (1983). 17

On the eve of the monetary reform PATAM (demand and time) deposits were equal to half the lira-denominated money supply; by the end of 1979 they were three times the value of the lira-denominated money supply. Evidence for a drop in the demand for money can be obtained by looking at the implied elasticity of change in the money base ratio ( $h$ ) in Table 4 with respect to the change in inflation $(\pi)$. For the change from $1965 / 67$ to $1974 / 77$ we find $\pi \Delta h /(h \Delta \pi)=-0.64$ while for the change from $1974 / 77$ to $1978 / 80$ it is -0.82 and from $1978 / 80$ to $1981 / 83$ it is -1.09 . Another piece of indirect evidence can be obtained by 
With a shift in demand away from Israeli-currency denominated assets underway, increased rates of inflation were consistent with relatively low rates of money and particularly money-base growth.

At the end of 1978 a restrictive credit policy was undertaken - by the Bank of Israel acting independently of the Treasury - in an attempt to stabilize the growing balance of payments deficit and control inflation. Ceilings were placed on the expansion of bank credit, but with free capital movements, imports of capital replaced domestic credit as a source of financing. The restrictive policy thus failed to reduce the growth of credit. The capital inflow problem was solved only in 1979, when capital imports were first prohibited and then permitted - subject to heavy taxation.

By that stage, however, the inflation rate was already well above its previous levels, and it would have taken a prolonged period of restrictive policy to reduce it. The second oil shock struck in 1979 , with costs to the economy that exceeded those of the first oil shock. There was thus a sizable supply shock. ${ }^{18}$ At the same time, the domestic deficit of the government rose. Monetary policy exerted some restraining influence by keeping the growth rate of bank credit low; once again low growth rates of the monetary base and the Israeli-currency denominated money supply were consistent with high rates of inflation because real demand for these

looking at the relative increase of currency in circulation compared to demand deposits in shekels. Between 1976 and 1978 deposits grew by 102 percent while currency grew by only 74 percent, whereas in 1979 the numbers are 31 and 41 percent, respectively (1979 is when the large PATAM increase took place).

18 As Figure 2 shows, real import prices rose much more during the second oil shock than during the first. 
assets fell. Despite the supply shock, demand policies allowed real GNP to rise by more than 5 percent in 1979; demand rose by more than 6.5 percent, and the current account deficit thus worsened.

\section{Attempts to Arrest Inflation}

With inflation firmly established in the three-digit range by the third quarter of 1979, and the government and the current account deficits increasing, a new Finance Minister was appointed at the end of 1979. Finance Minister Hurwitz assumed office determined to reduce the inflation rate and the current account defictt the old-fashioned way, by cutting government demand and by restrictive monetary policy. The initial cuts in government spending took the form of reduced subsidies, which immediately raised the price level, so that the inflation rate for the last quarter of 1979 was 168 percent. Monetary policy was defined in terms of the expansion of credit for domestic purposes; export credits were freely granted.

The Hurwitz policy raised unemployment from less than 3 percent in 1979 to over 5 percent in 1980 (see Figure 3), and sharply reduced the current account deficit by cutting imports. Despite growing unemployment, $\bar{G} \overline{N P}$ increased in 1980, although domestic demand fe11. The real exchange rate stayed virtually constant, so that most of the improvement in the balance of payments was due to the fall in domestic income and the depletion of stocks. Monetary policy defined in terms of the nominal increase in bank credit was restrictive throughout the year, particularly in the first half, and the rate of investment fell.

One might ask why Hurwitz's policies reduced employment without reducing inflation until much later. In the first place, the initial measures taken to cut the budget deficit were themselves inflationary. In 
the second, it is typical that a recession starts with output falling before inflation.

By the middle of the year, with the balance-of-payments deficit significantly reduced, political support for maintenance of contractionary policy was weakening, particularly in light of the approaching elections; the end of these policies was marked by the Finance Minister's resignation at the end of the year. There has not subsequently been an episode in which conventional contractionary policies were used in an attempt to reduce the inflation rate.

The beginning of 1981 saw the introduction of a new anti-inflationary policy, under Finance Minister Aridor. The policy, introduced before the June 1981 elections, was to keep inflation rates down by working on the cost side, and by keeping controlled prices from rising rapidly. Subsidies were accordingly increased, import tariffs slashed, and the exchange rate appreciated. Similar policies had been undertaken before other elections, though not with the same boldness. The policies had the desired effects, seen most clearly in an 80 percent (real) increase in consumer durable imports, and a fall in the inflation rate during the year (this may, in part, reflect a delayed response to the earlier Hurwitz contractionary policy). The budget deficit increased sharply, and monetary policy was accommodating in that nominal magnitudes, with the exception of bank credit, rose more rapidly than prices. The balance-of-payments deficit also worsened.

The expansionary policies of 1981 began to take their toll in a rising inflation rate in the first three quarters of 1982 . At this point a new inflation stabilization policy was introduced, following the lines of the policy of early 1981. The hope was to move the economy to an inflation 
rate of 5 percent per month by keeping the rate of increase of the exchange rate and controlled prices to that rate. The belief was that these measures, together with their effects on expectations, could move the economy to a new lower inflation equilibrium.

The policy succeeded in bringing the inflation rate down somewhat, but monetary policy was not supportive of the 5 percent inflation rate; all nominal magnitudes were expanding at well above 100 percent per year. This may explain the asymmetry of response to downward adjustments in the exchange rate that was recorded earlier. Domestic prices were still rising at more than 100 percent per year implying a rapid real exchange rate appreciation, and accompanying increasing current account deficit. At the same time, the real wage was rising rapidly (see Figure 2).

The anti-inflationary policies were buying short-run success at the cost of a later inflationary outburst when the nomina1 and real exchange rates would have to be adjusted to deal with the current-account deficit. Real wages and income levels would likewise have to be reduced to levels more commensurate with domestic resources.

The failure of the Aridor policies is a result of the unwillingness to reduce aggregate demand sufficiently to justify the new 5 percent per month equilibrium. Even if, in principle, the economy did have another lower inflation equilibrium with the same policies, ${ }^{19}$ fiscal and/or monetary policy should have been tightened early in the Aridor program when it was clear that the real exchange rate was appreciating and that the policy could not be sustained.

19 With the growth rate of high-powered money the only nominal anchor in the system, it is possible that there is another lower inflation equiibrium for the economy with unchanged fiscal policy variables, and the same amount of revenue being obtained from the printing of money. 
When the long-delayed devaluation took place in October 1983, it once more caused jumps in the price level and in the inflation rate. The price level increased by more than 50 percent from September to December 1983, while the exchange rate increased by 68 percent over the same period. Cuts in subsidies contributed to the rise in prices. The real wage fell substantially over this period, once more showing the effects of the lags in the indexation system and the less than 100 percent indexation of wages to prices. The rate of inflation fell in the first quarter of 1984 to the 300 percent range, but still remained well above the levels before the devaluation.

Any prospects for restrictive monetary and fiscal policy vanished with the announcement of elections for July 1984. The government once more increased subsidies and slowed the devaluation rate to less than the inflation rate. After a remarkably long period of quiet labor relations following the devaluation, labor negotiations in the second quarter of 1984 resulted in nominal wage increases that restored real wage levels to the pre-October 1983 levels. With monetary and fiscal policy expansionary, with the need for a post-election correction of the exchange rate becoming evident, and with widespread uncertainty about the type of policies to be followed after the elections, the inflation rate remained in the $300-400$ percent range, and the black market exchange rate opened up a 25 percent premium over the official rate.

\section{Shifts in the Inflation Rate - A Steady-State View}

While our approach to inflation dynamics may explain short-run shifts in inflation, it does not of itself provide an account of the components of the underlying long-run inflation rate. One summary way of looking at the 
latter is to apply the framework of equation (12) to the determinants of the monetary base and the implied steady-state inflation rate. For each sub-period we may calculate the difference between the ratio of domestic government finance $(\delta)$ and the part of the growth in net financial assets (money and debt) that individuals would be willing to hold given GNP growth and the average financial asset ratio $\left[g_{y}(h+b)\right]$. The ratio of the resulting net injection to the money base should be consistent with the underlying inflation rate. 20

The components of this calculation are shown in Table 4 and the resulting index appears in line 7 and is compared in line 8 with the mean inflation rate, by sub-period. Since the money base ratio is itself a function of the inflation rate, and the falling GNP growth rate, too, may at least partly be related to rising inflation, one should not interpret this comparison in pure one-way causality terms. It does, nonetheless, indicate that the shift in the underlying inflation rate from one phase to another could be related to three important respective developments: the rise in the deficit $\delta$ between the two wars (1968-73), the fall in the growth rate after the $1973-74$ crisis, and the probable drop in the demand for money in the period after 1977 . It is interesting to note that the index points to an implied money-base growth rate (267 percent) that is higher than actual inflation (141 percent) during 1981-83. By the end of 1983, we remember, inflation did in fact catch up with this higher figure. While the actual jump in inflation in October 1983 may be attributed to the dynamic effects of a delayed devaluation in a perfectly accommodated

20 For an empirical application of this framework to the analysis of the jumps in the inflation rate see Melnick (1983) and Melnick and Sokoler (1984). A similar framework was first discussed by N. Liviatan. 
monetary system, this calculation at least shows that the more recent jump was not inconsistent with the underlying fiscal and monetary determinants.

\section{POLICY ISSUES}

\section{The role of indexation}

Indexation is at the top of most lists of villains in the Israeli inflation. Any analysis that blames indexation for the inflation has to contend with the fact that indexation has been widespread in the Israeli economy since the $1950 \mathrm{~s}$, whereas the inflation rate did not reach exaggerated levels until the 1970 s.

The standard view that indexation is to blame for inflation is correct in the sense that without indexation, the costs of inflation would have been so high that the inflation rate would not have reached its current levels. The government would have been forced to stabilize well before the three-digit range was reached.

Beyond this valid point, we distinguish between the roles of indexation of wages and indexation of the values of financial assets. Because wage indexation is less than 100 percent, the pattern of typically increasing real wages seen in Figure 3 could not have been attained without discretionary wage fixing, especially in more recent years. There is no reason to think that labor would have been more willing to take real wage cuts in the absence of indexation; nor, given the lags in indexation, is it likely that nominal wages would have adjusted significantly more slowly in the absence of indexation.

Indexation of financial asset returns does, however, significant1y reduce the automatic stabilization of the economy. Price and exchange-rate 
shocks automatically affect the nominal value of large stocks of assets. The effect of a given devaluation on the balance of payments is thereby also reduced. More active accompanying fiscal policy could compensate for the loss of automatic stabilization, but variations in government spending and taxes are neither costless nor easily achieved.

The difficulties created for the stability of the system by the debt are a result not only of indexation but also of the size of the debt. If the debt were small, as it had been in the $1950 \mathrm{~s}$ and $1960 \mathrm{~s}$, the change in the nominal value of wealth resulting from a given shock to prices or the exchange rate would also be small, and the stabilizing power of the real balance effect would be proportionately greater. Further, the continued issuance of indexed as opposed to nominal debt can itself be viewed as an endogenous response to the need to finance large budget deficits: the public simply would not have been prepared to lend to the government on terms that gave the government the option to repudiate the debt through inflation. 21

So long as the debt and inflation continue to be large, there is no prospect for shifting to a different structure of assets, though steps could be taken to reduce the liquidity of the debt. A sharp cut in the government budget deficit sufficient to begin reducing the debt/GDP ratio would eventually both reduce the difficulties created by the indexation of

21 It is not obvious that an optimizing trustworthy government operating in an environment with considerable macro-risk should issue indexed debt. The issue is complicated by the inter-generational nature of the risk-sharing implied by public debt issue: issuing indexed debt gives the current generation of savers a claim of fixed value on later generations of producers. The question of the optimal form of government debt issue is closely connected with the problem of dynamic inconsistency; see Lucas and Stokey (1983). 
the debt and make it possible to begin issuing different types of debt. 22

\section{The costs of inflation}

There has been very little research on the costs of inflation in Israel. The co-incidence of the rise in the inflation rate after 1973 with the reduction in the growth rate is generally suspected to be more than that: in one direction we have already seen above that a fall in the growth rate is 1 ikely to increase the inflation rate; less firmly established is the causal link from high inflation to low growth. It is not sufficient to point to the Israeli experience, for there has been a worldwide reduction in the growth rate of output, shared by countries like Japan where the inflation rate fell from the 1960s, and countries like Israel where the inflation rate increased. While we believe that the continuation of inflation in Israel is partly to blame for low growth, we are uncomfortably aware that the case has not been proved.

One source of the relationship between the growth rate of output and rising inflation may be the increasing diversion of resources to financial activities as inflation increases. Preliminary results by Kleiman (1984) suggest that increasing activity in the financial sector absorbed an extra 3-4 percent of GNP by 1982. The wel1-known measure of the costs of anticipated inflation as the area under the demand curve for high-powered money

21

Indexation of debt in Israel applies almost entirely to government bonds. There has been virtually no private issue of indexed debt; behind every major, apparently private-sector indexed liability (such as long term savings accounts in banks, or indexed life insurance) stand government indexed bonds. The government is active as a financial intermediary, borrowing indexed from the public to make (until 1979) non-indexed loans to the private sector, or to offer subsidized credit for exports, housing, and other forms of investment. 
gives estimates of the cost of 160 percent inflation as being about 2-3 percent of GNP. This is an alternative estimate of the increased absorption of resources in making financial transactions.

These are useful lower bound estimates of the costs of inflation, but familiar stories of the increasing inefficiency of the price system, the diversion of managers' time to financial instead of real output decisions, the inefficiency and - with rising inflation - the progressive breakdown of the tax system, and so forth, suggest the costs are much higher.

However, the existence of indexed assets in Israel means that one of the major costs of and concerns about (uncertain) inflation - the inability to protect the real value of savings - is not present, or at least is present only to the extent that there is uncertainty about the government's ability to meet its formal commitnents. This difference accounts for the lesser public concern expressed about inflation in Israel than in other countries with much lower inflation rates.

\section{Public opinion about inflation}

There has not been any overwhelming pressure of public opinion in Israel to end the inflation. In part this has been because there are pressing non-economic issues before the electorate; in addition, the costs of inflation are not perceived to be great.

The indexation system protects the public from what in other countries would be the major costs associated with high and uncertain inflation. Further, although the rise in inflation in Israel was accompanied by slower growth, it has in recent years also been accompanied by a rapidly rising standard of living. For the years 1980-1983, private consumption increased by 28 percent (while GNP grew only 6 percent). Under these 
conditions the public may be excused for not seeing a pressing need to end inflation - particularly when it is well known that the adjustment process would require a transitory period of unemployment.

\section{Stabilization programs}

We do not provide a full discussion here, rather touching on the issues that have been raised in the debate.

The economy is seen as facing both real and nominal problems. On the real side the balance-of-payments deficit is viewed as too large, leaving the economy sensitive to both political pressure from the United States government and to changes in opinion in the world capital markets; similarly, the budget deficit is too large, implying a national debt that is growing too rapidly, and diverting too much of the private sector's saving to government debt. On the nominal side, there is a need to reduce the inflation rate and the sensitivity of the price level to shocks hitting the economy.

The first set of issues are those of whether to attempt to stabilize, and how rapidly. As the inflation rate has increased, economists have moved increasingly towards the views that reducing the inflation rate back to the low double digit range is desirable, and that this could only be carried out through a comprehensive stabilization program that attempts to make the adjustment rapid1y rather than gradually. The conclusion that inflation should be ended has been reached because of the increasing perception of the economy and the financial system as out of control, tending over time always to higher inflation rates, and with an increasing frequency of balance of payments crises. The low growth - high inflation correlation of the economy has also influenced the argument. 
The conclusion that the program should be comprehensive and rapid has been reached on political economy, and not purely economic, grounds. The failure of successive governments since 1977 to persist with restrictive policies for periods of much more than half a year raises the fear that any gradualist program in which restrictive policy - for instance, a continuing series of budget cuts - is supposed to be maintained over several years is unlikely to be followed through by the government. Hence the conclusion that the tough medicine should be taken all at once.

The Iist of measures included in the program starts from a cut in the budget deficit. The justification for and the proposed size of cuts varies: for instance Liviatan and Piterman (in this volume) argue that the budget deficit matters mainly because it affects the balance of payments, and that a cut in the deficit of 3-4 percent of GNP would be sufficient; others (ourselves included) point to the large and growing debt as so constraining monetary policy (because of the need to roll over the debt and prevent rising interest payments from making the budget deficit larger) and increasing the likelihood of future crises that it is essential to move rapidly to a balanced budget so that the debt/GNP ratio can start ć falling.

It is also generally agreed that in the long run monetary policy should play a stronger role in the economy, with perhaps explicit adoption of monetary growth targets. Strict adherence to monetary targets in an extremely open economy is, however, unlikely, for exchange rate disturbances originating abroad will at times have to be offset by monetary policy.

The difficult issues of a stabilization program arise in discussion of the measures that should accompany the initial budget cuts, in the attempt 
to minimize the unemployment costs of the transition to a low inflation equilibrium. One approach that has received support is to attempt to move almost immediately to a zero or low inflation equilibrium through an agreement with the Histadrut to freeze nominal wages, by fixing the exchange rate, and by attempting to control prices. The difficulty in this approach is that the program will have to start with a real devaluation and changes in relative prices of goods, that would certainly make it difficult to control the absolute level of prices - or alternatively could lead to damaging relative price distortions and greater unemployment. Another difficulty with this approach is that it is almost certain that readjustments of prices and the exchange rate will be necessary after some time, and that these readjustments could reignite inflation.

An alternative approach would first implement budget cuts and wait for unemployment to emerge before trying to reduce the inflation rate through a co-ordinated package of measures. This approach can be seen as trying to solve the real problem first and the nominal one later. The danger in this approach is that the large unemployment costs incurred at the beginning would lead to the abandonment of the second-stage inflation reduction part of the program.

The issue of how to handle the large stock of indexed assets in the economy during this transition period and for the future stability of the economy has also received attention. There have been many proposals to reduce the liquidity of the dollar-indexed PATAM accounts, though less detail on how to do this; there was also at the time of writing fear that a new government would in some way reduce the value of these assets as part of a stabilization program. A capital levy, which would reduce the value of the outstanding debt without taxing especially those who had in 
the past purchased government debt was also on some agendas.

Finally, we briefly discuss the dollarization alternative that was proposed at the end of 1983 by Finance Minister Aridor in the wake of the fallure of his previous policies. If the Israeli economy were indeed to move to complete use of the dollar, its long-run inflation rate would be that of the United States ${ }^{23}$ and inflation would be ended quickly. There is no guarantee, however, that such a change would reduce the unemployment costs of the transition to a lower inflation rate.

From a purely economic viewpoint dollarization is undesirable because the country would pay to the United States government the revenue that it would otherwise be obtaining for itself through the printing of money. In addition, Israel would be accepting the American exchange rate vis-à-vis other currencies: for instance, if Israel had been on the dollar in the last few years its currency would have appreciated substantially relative to Europe. This would not have been desirable.

There are of course nationalist reasons not to dollarize. Adoption of a well planned stabilization program would make it less likely that dollarization would in the end be the only available solution for the economy.

23 Except for minor deviations arising from changes in the prices of nontraded goods. 
Table 1. Inflation Rate, Growth Rate, Current Account Deficit, and Relative Price Changes, 1960-1984

(Annual percentage rates, based on quarter1y compounding)

\begin{tabular}{|c|c|c|c|c|c|c|c|c|}
\hline \multicolumn{2}{|c|}{ Phase } & $\begin{array}{c}\text { Number } \\
\text { of } \\
\text { quarters } \\
\text { (1) }\end{array}$ & $\begin{array}{l}\text { CPI } \\
\text { change } \\
\text { (2) }\end{array}$ & $\begin{array}{l}\text { GNP } \\
\text { growth } \\
\text { (3) }\end{array}$ & $\begin{array}{l}\text { Curr. } \\
\text { Acct. } \\
\text { deficit/ } \\
\text { GDP } \\
\text { (4) }\end{array}$ & $\begin{array}{l}\text { Real } \\
\text { export } \\
\text { price } \\
(5)\end{array}$ & $\begin{array}{l}\text { Real } \\
\text { import } \\
\text { price } \\
(6)\end{array}$ & $\begin{array}{l}\text { Real } \\
\text { wage } \\
\text { in } \\
\text { mfg. } \\
(7)\end{array}$ \\
\hline 1 & $\begin{array}{l}\text { Normal } \\
\text { growth } \\
60: 1-65: 1\end{array}$ & 20 & 6.8 & $9.6^{\mathrm{a}}$ & $19.9^{\mathrm{a}}$ & $9.3^{\mathrm{a}}$ & $2.7^{\mathrm{a}}$ & 3.4 \\
\hline 2 & $\begin{array}{l}\text { Recession } \\
65: 1-67: 2\end{array}$ & 9 & 6.1 & -1.5 & 15.3 & -1.1 & -4.8 & 5.2 \\
\hline 3 & $\begin{array}{l}\text { Recovery } \\
67: 2-70: 1\end{array}$ & 11 & 2.0 & 14.6 & 18.5 & 4.7 & 6.4 & 2.4 \\
\hline 4 & $\begin{array}{l}\text { Boom } \\
70: 1-73: 3\end{array}$ & 14 & 14.4 & 9.1 & 22.0 & 2.2 & 2.9 & 2.2 \\
\hline 5 & $\begin{array}{l}\text { War and } \\
\text { oil shock } \\
73: 3-77: 2\end{array}$ & 15 & 36.0 & 2.6 & 30.9 & -0.7 & -0.4 & 2.9 \\
\hline 6 & $\begin{array}{l}\text { Traverse } \\
77: 2-79: 4\end{array}$ & 10 & 71.0 & 3.0 & 23.5 & 5.3 & 4.8 & 1.0 \\
\hline 7 & $\begin{array}{l}\text { P1ateau } \\
79: 4-83: 3\end{array}$ & 15 & 123.3 & 1.6 & 19.6 & -2.9 & -3.5 & 7.5 \\
\hline 8 & $\begin{array}{l}\text { Kunaway } \\
\text { inflation } \\
83: 3-84: 1\end{array}$ & 2 & 369.0 & & & & & \\
\hline
\end{tabular}

a Calculated from annual data.

Definitions

Col. (4): Total deficit divided by GDP (this is a level ratio).

Col. (5): Rate of change of export prices, at effective exchange rate, deflated by CPI.

Col. (6): Rate of change of domestic import prices, at effective exchange rate, deflated by $\mathrm{CPI}$.

Sources: Calculated from quarterly national accounts, Central Bureau of Statistics. 
Table 2. Financing of the Government Budget, 1960-1983

(percent of GDP)

\begin{tabular}{|c|c|c|c|c|c|c|c|}
\hline $\begin{array}{l}\text { Domes- } \\
\text { tic } \\
\text { expen- } \\
\text { diture }\end{array}$ & $\begin{array}{l}\text { Net } \\
\text { foreign } \\
\text { expen- } \\
\text { diture }\end{array}$ & Taxes & $\begin{array}{l}\text { Domestic } \\
\text { deficit } \\
\text { (1)-(3) }\end{array}$ & $\begin{array}{c}\text { Total } \\
\text { deficit } \\
(4)+(2)\end{array}$ & $\begin{array}{l}\text { Base } \\
\text { money } \\
\text { crea- } \\
\text { tion }\end{array}$ & $\begin{array}{l}\text { Domes- } \\
\text { tic } \\
\text { debt } \\
\text { finance }\end{array}$ & $\begin{array}{c}\text { Foreign } \\
\text { debt } \\
\text { finance }\end{array}$ \\
\hline
\end{tabular}

(3)

(4)

(5)

(6)

(7)

\begin{tabular}{|c|c|c|c|c|c|c|c|c|}
\hline $1960-64$ & 27.0 & 1.2 & 28.8 & -1.8 & -0.6 & 2.5 & -3.3 & 0.3 \\
\hline $1965-67$ & 32.0 & 2.8 & 29.6 & 2.4 & 5.2 & 2.2 & 0 & 3.0 \\
\hline $1968-73$ & 41.0 & 6.6 & 34.4 & 6.6 & 13.2 & 3.2 & 5.4 & 4.6 \\
\hline $1974-77$ & 56.4 & 3.3 & 42.1 & 14.3 & 17.6 & 2.6 & 4.7 & 10.4 \\
\hline--- & -- & --- & -- & --- & -- & -- & -- & -- \\
\hline $1978-80$ & 60.7 & 2.0 & 45.5 & 15.2 & 17.2 & 2.0 & 7.3 & 6.9 \\
\hline $1981-83$ & 61.0 & -0.3 & 46.5 & 14.4 & 14.1 & 2.1 & 7.2 & 4.9 \\
\hline $1983^{a}$ & 59.0 & -0.2 & 48.1 & 10.9 & 10.7 & 2.3 & 1.4 & 7.0 \\
\hline
\end{tabular}

Definitions:

(1) Domestic expenditure includes goods and services, subsidies, transfers and interest on the public debt.

(2) Net foreign expenditure is defined as government expenditure abroad (mainly armaments) plus interest on debt minus unilateral transfers (mainly U.S. government).

(3) Taxes include all direct and indirect taxes and transfers to government.

$(4)=(1)-(3)$.

$(5)=(1)+(2)-(3)=(6)+(7)+(8)=$ Total finance of deficit.

(7) Domestic debt finance incorporates indexed bonds and, after 1977, also the Bank of Israel PATAM accounts. Figures are net of repayments and of loans to the public sector ( 8.9 percent in 1968-73, 4.3 percent in 1974-77, and very small afterwards.

\section{Sources:}

1960-80 - L. Meridor (1983, unpublished).

1981-83 - Bank of Israel Report, 1983 (to be revised).

Definitions of columns (1), (4), (7) slightly altered between two sources (by the order of no more than $1-2$ percent). 
Table 3. Monetary Variables, 1960-1983

(Annual percentage growth rates ${ }^{\mathrm{a}}$ )

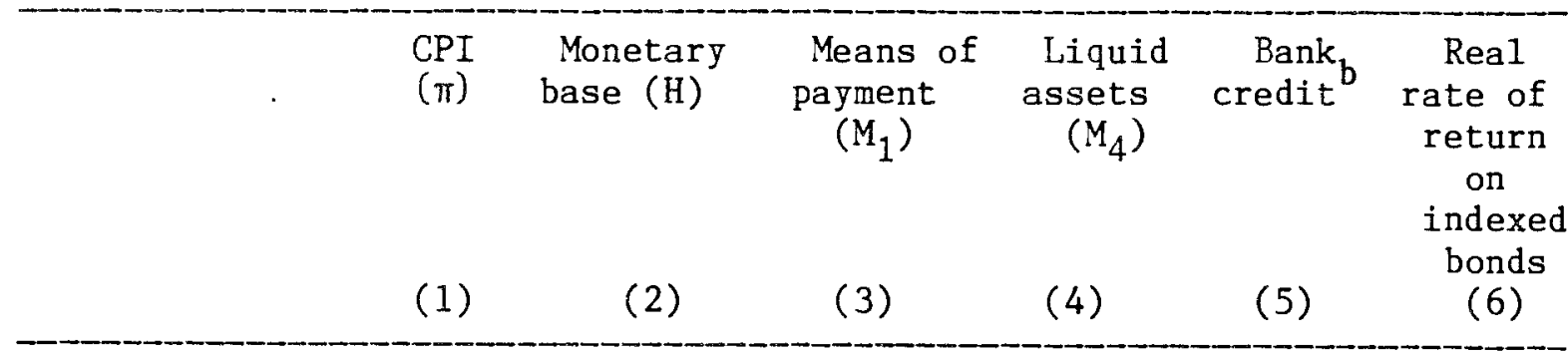

1 Norma1

growth

$60: 1-65: 1$

$\begin{array}{lll}6.8 & 18.2 \quad 17.4\end{array}$

2 Recession

$65: 1-67: 2$

$6.1 \quad 10.6 \quad 16.4$

3 Recovery

$67: 2-70: 1$

2.0

4.7

9.1

4 Boom

$70: 1-73: 3$

14.4

34.9

24.8

35.7

5 War and

oil shock

$73: 3-77: 2$

36.0

23.8

26.5

28.7

44.8

$2.1^{c}$

6 Traverse

$77: 2-79: 4$

71.0

25.8

37.0

$75.1 \quad 102.9$

2.3

7 Plateau

$79: 4-83: 3$

123.3

103.2

97.1

126.6

106.1

$2.5^{\mathrm{d}}$

\footnotetext{
a Columns (1) to (5) based on quarterly compounding.

b Net of fuel credit.

c Mean 75-76.

d Mean 80-82 (in 1982 it was 1.9).
}

Source: Bank of Israel. 
Table 4. Government Injection to Money Base and the Rate of Inflation

\begin{tabular}{lccccc}
\hline & $1965-67$ & $1968-73$ & $1974-77$ & $1978-80$ & $1981-83$ \\
\hline $\begin{array}{l}\text { 1. Financial asset ratio } \\
(\mathrm{h}+\mathrm{b})\end{array}$ & $(0.5)$ & 0.6 & 1.0 & 1.1 & 1.3 \\
$\begin{array}{l}\text { 2. Percentage money base } \\
\text { to GNP (h) }\end{array}$ & 12.5 & 13.4 & 9.8 & 5.2 & 2.7 \\
3. Percentage GNP growth $\left(\mathrm{g}_{\mathrm{y}}\right)$ & 3.2 & 10.3 & 2.6 & 3.5 & 1.6
\end{tabular}

4. Domestic government

$\begin{array}{llllll}\text { finance ratio }(\pi) & -2.2 & 8.6 & 7.3 & 9.3 & 9.3\end{array}$

5. Of which:

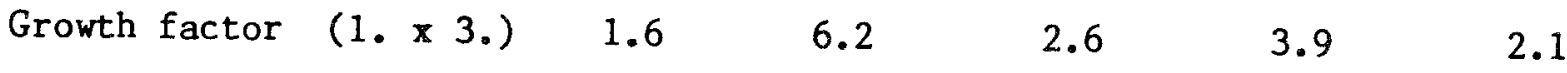

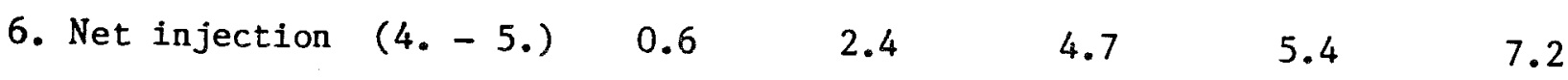

7. Net injection / money base $(6 . / 2$.

$\begin{array}{lllll}5 & 18 & 48 & 104 & 267\end{array}$

$\begin{array}{llllll}\text { 8. Inflation rate (percent) } & 5 & 11 & 40 & 97 & 141\end{array}$

\section{Sources:}

Line 1. Yariv (1982); 1965-67 figure assumed same as $1970 ; 1968-73$ is the
average for $1970-73$.

Line 2. Bank of Israe1.

Line 3. Central Bureau of Statistics.

Line 4. Columns (6) + (7) of Table 2.

Line 8. Central Bureau of Statistics.

Note: 1981-83 data are subject to revision. 


\footnotetext{
Figure 1. Rate of CPI Inflation

(Annual percentages, each quarter over same quarter previous year)
}

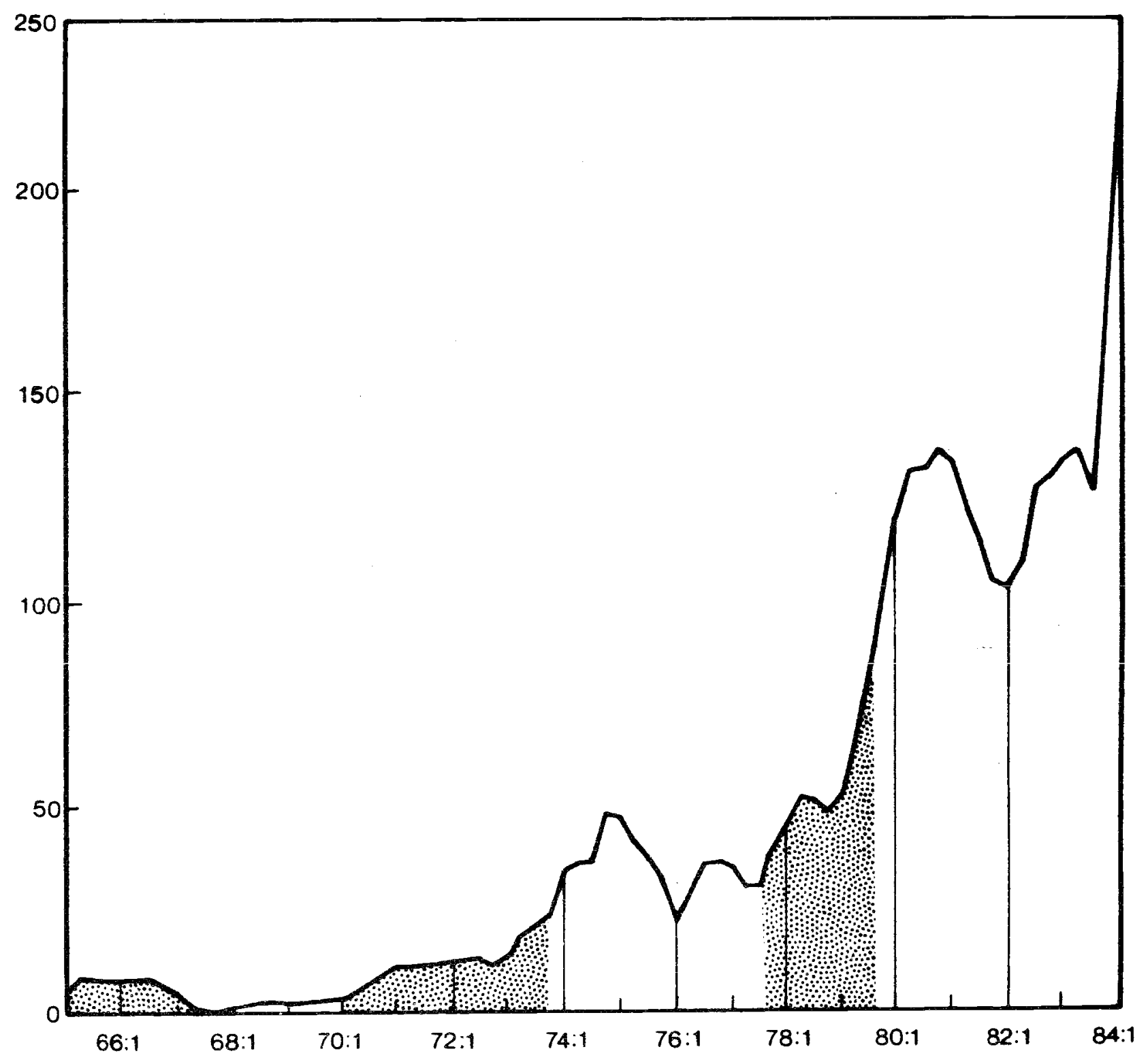


Figure 2. Real Import Prices and Real Wages, 1965:2-1983:4

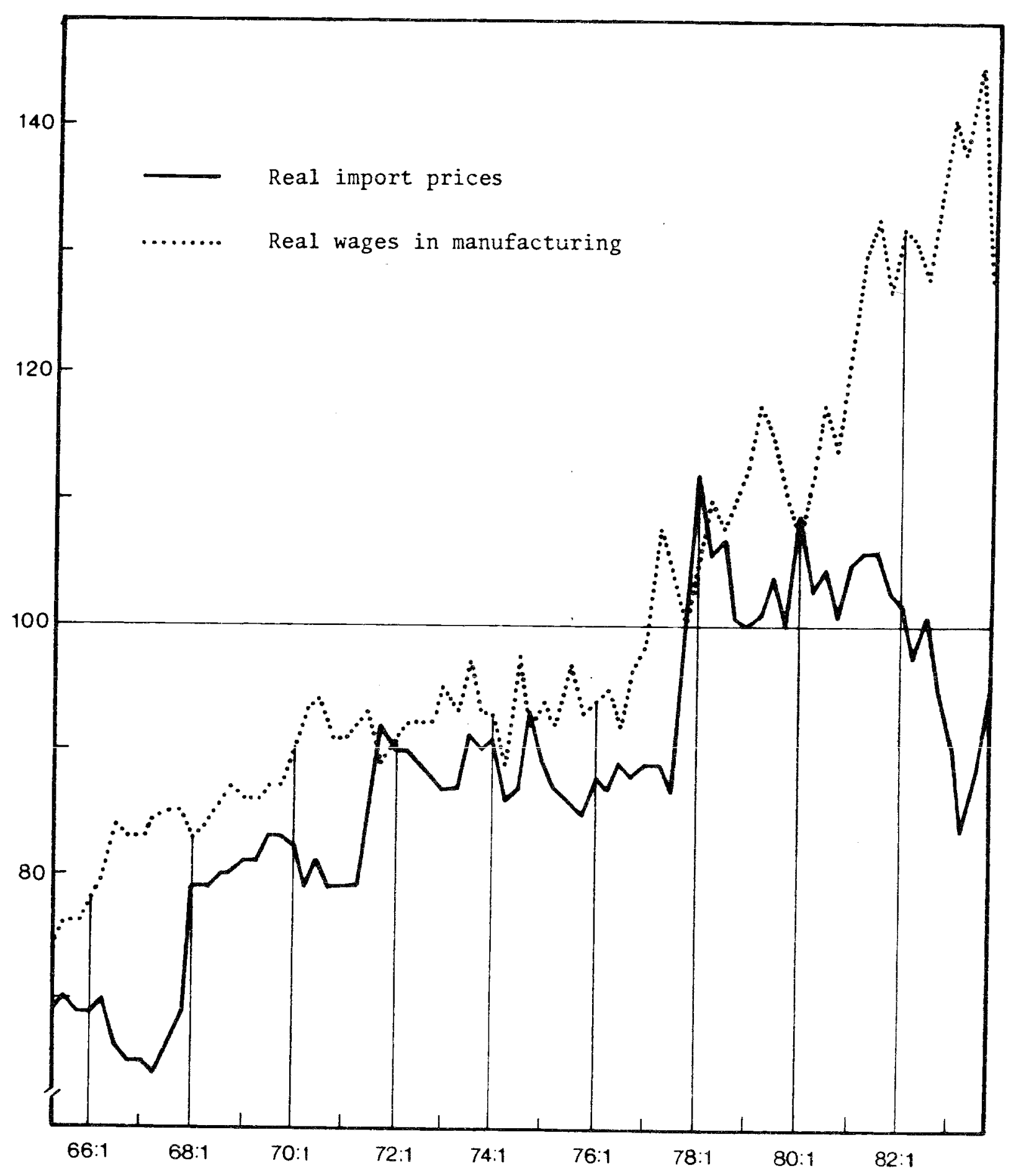


Figure 3. The Unemployment Rate, 1963-1983

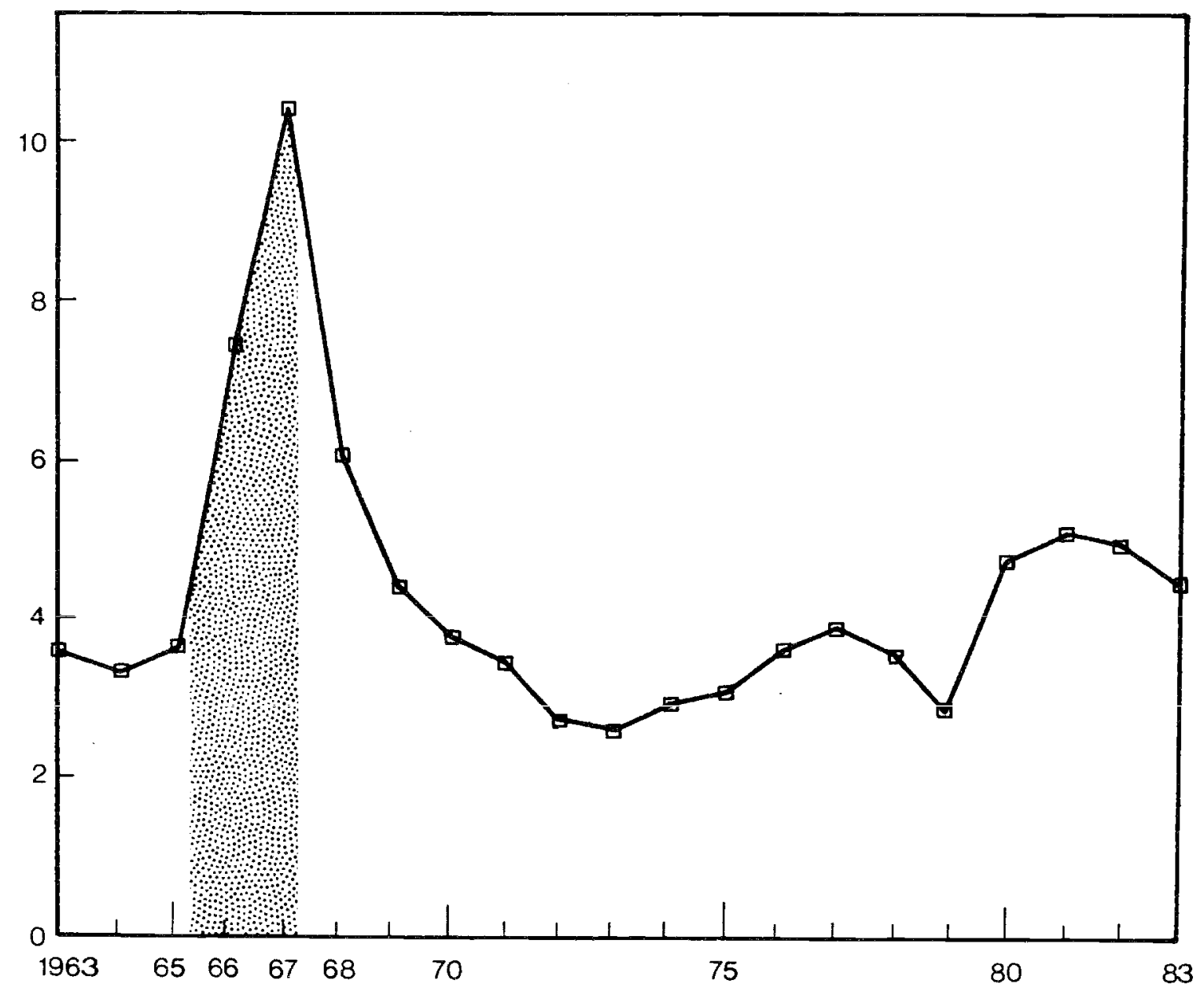




\section{REFERENCES}

Artstein, Y. and Z. Sussman. 1977. "Wage and Price Controls and the Effectiveness of Devaluations: The Israeli Experience." Jerusalem: Bank of Israel.

Bruno, M. 1984. "External Shocks and Domestic Response: Israel's Macroeconomic Performance 1965-1983." Jerusalem: The Maurice Falk Institute for Economic Research in Israel, Discussion Paper No. 84.01. and Z. Sussman. 1979. "Exchange Rate Flexibility, Inflation and Structural Change: Israel Under Alternative Regimes." Journal of Development Studies, 6: 483-514. and - 1981. "Floating Versus Crawling: Israel 1977-79 by Hindsight." In J. Williamson (ed.), Exchange Rate Rules. London: Macmillan.

Fischer, S. 1984. "The Economy of Israe1." Carnegie-Rochester Conference Series on Public Policy, Vol. 20, 7-52.

Gottlieb, D. and S. Peterman. 1982. "Inflationary Expectations in Israel, 1965-1980." Jerusalem: Bank of Israel Research Department Discussion Paper 82-1 (Ápri1). Hebrew.

Kleiman, E. 1984. "The Cost of Inflation." The Economic Quarterly. 30 (No. 119, January): 859-684. Hebrew.

Leiderman, L. and A. Marom. 1983. "New Estimates of the Demand for Money in Israe1." Jerusalem: Bank of Israel Research Department Discussion Paper 83.09 (October).

Liviatan, N. and S. Piterman. 1984. "The Inflationary Process in the Israeli Economy." Draft. Jerusalem: Bank of Israel Research Department. Hebrew.

Lucas, R. and N. Stokey. 1983. "Optimal Fiscal and Monetary Policy in an 
Economy without Capital." Journal of Monetary Economics. 12 (No. 1): 55-94.

Melnick, R. 1983. "Two Issues in the Demand for Money." Jerusalem: Bank of Israel Research Department Discussion Paper 83-06 (October). Hebrew. and M. Sokoler. 1984. "The Government's Revenue from Money Creation and the Inflationary Effects of a Decline in the Rate of Growth of GNP." Journal of Monetary Economics. 13 (No. 2, March):225-236.

Meridor, L. 1983. "The Government Budget Identity in Israel 1960-1980." Draft. Jerusalem: Bank of Israel Research Department (August). Hebrew.

Yariv, D. 1982. "The Development of Wealth in Israel 1970-1981." Draft. Jerusalem: Bank of Israel Research Department (October).

Zilberman, G. 1984. "Econometric Model of Prices and Wages in Israel 19611980." Jerusalem: The Maurice Falk Institute for Economic Research in Israel (forthcoming). Hebrew. 